DOI: https://doi.org/10.47405/mjssh.v5i5.421

\begin{tabular}{|c|c|}
\hline 4 & Malaysian Journal of Social Sciences and Humanities (MJSSH) \\
\hline $\begin{array}{l}\text { Malaysian Journal of } \\
\text { Social sciences and }\end{array}$ & Volume 5, Issue 5, May 2020 \\
\hline (MJ-SSH) & e-ISSN : 2504-8562 \\
\hline & $\begin{array}{l}\text { Journal home page: } \\
\text { www.msocialsciences.com }\end{array}$ \\
\hline
\end{tabular}

\title{
Dapatan Data Melalui Projek Rintis: Penjarian Index, Middle, Ring (IMR) dalam Frasa Solo Bes
}

\author{
Mohd Shahri Bin Ramli1 \\ ${ }^{1}$ Fakulti Kemanusiaan Seni dan Warisan, Universiti Malaysia Sabah (UMS) \\ Correspondence: Mohd Shahri Bin Ramli (shahriramli@hotmail.com)
}

\begin{abstract}
Abstrak
Penulisan ini tertumpu kepada dapatan data dari projek pilot kajian teknik penjarian IMR (Index, Middle, Ring) yang menekan bod jari bes elektrik dalam melakukan persembahan solo bes. Penentuan kelajuan jari melakukan peralihan dan lintasan tali, artikulasi teknik hammer on, pull off dan trill serta kekuatan jari unuk melakukan teknik bending antara permasalahan penjarian yang timbul semasa melakukan persembahan solo bes. Oleh itu, perungkaian penjarian IMR dalam menyediakan pilihan jari untuk melakukan persembahan solo bes akan dikaji dalam membantu membendung pemasalahan ini. Projek pilot melalui kajian ini adalah projek eksperimentasi pembacaan keratan nota muzik yang mana di dalam nota muzik tersebut memiliki elemen yang merangkumi pemasalahan dan objektif kajian. Keratan notasi ini dicipta mengikut kesesuaian inti pati kajian dan dicaturkan kesemuanya pada satu frasa notasi solo yang panjang sekitar 10 bar. Elemen yang ditampilkan adalah hasil rujukan 4 solo bes yang telah ditranskrip dari 4 pemain bes terkemuka. Peralihan dan perlintasan jari diambil dari rujukan solo bes Tom Kenedy dan Geddy Lee. Perlenturan not merujuk kepada solo bes Jaco Pastorius. Artikulasi Hammer On, Pull Off dan Trill adalah melalui Jeff Andrew dan Geddy Lee. Projek pilot ini melibatkan 8 pemain bes dari kalangan pelajar diperingkat Diploma dan Sarjana Muda. Pemilihan pemain bes ini dipilih mengikut syarat kaedah yang telah ditetapkan. Proses projek pilot ini telah mengambil masa beberapa jam untuk diselesaikan. Melalui penghasilan data pilot projek ini akan menunjukkan keberkesanan teknik penjarian IMR dalam mengatasi pemasalahan dan membantu mencapai objektif kajian.
\end{abstract}

Kata kunci: teknik penjarian, solo bes, teknik penjarian Index, Middle, Ring (IMR), bass elektrik

\section{Pilot Project: Index, Middle, Ring (IMR) Fingering in Bass Solo Phase}

\begin{abstract}
This paper focuses on the data findings of a pilot project on IMR fingering technique (Index, Middle, Ring) on electric bass keyboard in executing bass solo performance. Difficulty in determining finger speed over shifting and string crossing, music articulation techniques such as hammer on, pull off and trill as well as finger strength to do bending technique are among the fingering problems that arises when performing bass solo. IMR fingering has characteristics such as scale suitability in playing a challenging phrase, unique shape structure of hold/grip on fretboard and can provide speed in finger movement while playing a phrase. Hence, IMR fingering as the finger choice to execute solo bass performance will be studied to overcome these issues. This research is an experimental pilot project on Etude where the music notes hold elements that cover the issues and the objectives of this research. A part notation is created and set to a phrase solo around $10 \mathrm{bar}$ to fit the core of this research. The
\end{abstract}


elements presented in this research are the result of reference to the works of four renowned bass players. Shift and cross fingering refer to Tom Kenedy and Geddy Lee while note bending refers to Jaco Pastorius. Jeff Andrew and Geddy Lee are cited as reference for Hammer On, Pull Off and Trill articulation techniques. This pilot project involves 8 bass players among diploma and degree students who are selected based on certain set of criteria. The findings of this research show the effectiveness of IMR fingering in resolving raised issues in bass solo performance.

Keywords: fingering technique, bass solo, Index, Middle, Ring (IMR) fingering technique, electri bass

\section{Pengenalan}

Dalam dunia persembahan muzik khususnya bass telah mengambil banyak perubahan sejak kemunculan nenek moyang pada sekitar tahun 1200. Menurut Mooter (2002), pada ketika itu Gigues bersaiz besar yang berfungsi mengeluarkan nada terendah telah wujud. Bass berkembang sehingga tahun 1890 yang mana Akustik bass atau juga dikenali sebagai double bass mula digunapakai dalam persembahan muzik jazz seperti big band dan kombo kecil (Rachel, 2011). Bass akustik atau double bass yang bersifat tidak mempunyai fret wujud disebabkan kebolehan menghasilkan frekuensi yang rendah atau seringkali dipanggil bass ton. Pada masa ini, double bass selalu digunakan dalam genra jazz dimana 'walking bass' selalu digunakan dalam era swing. Pada tahun 1920 sehingga 1950, perubahan muzik dengan penglibatan bass akustik berkembang iaitu bermula dengan swing, big band, diikuti bebop dan seterusnya hard bop.

Pada tahun 1930, Paul Tutmarc telah mencipta gitar bes pertama dengan bentuk moden yang memiliki fret dan dipegang secara mendatar. Pada tahun 1951, Leo Fender mula memperkenalkan gitar bes precision disebabkan ingin menbolehkan pemuzik memegang dan menahan instrumen mereka seperti gitar (Black J.W dan Albert, 2001). Pada tahun akhir 1960 dan awal 1970, muzik Jazz semakin berkembang sehingga wujudnya fusion Jazz iaitu percaturan muzik Rock dan Jazz. Pengwujudan pelbagai teknik pemainan gitar bass yang diselitkan pada muzik Jazz dan Rock seperti slapping, popping, tapping, hammer on serta pull off ${ }^{l}$ dan juga kombinasi bersama kesan bunyi (sound effect) telah menjadikan bass elektrik antara instrumen yang serba boleh.

Sering kali peranan bes elektrik dikaitkan dengan pengawalan irama atau bassline dalam persembahan bersama drum, alat muzik bes menjadi tulang belakang dalam membentuk citarasa sesebuah lagu (groove) $^{2}$. Pada sekitar tahun 1960, persembahan solo menggunakan gitar bes menjadi sesuatu yang baru dan pada sekitar akhir tahun 1960 dan awal 1970, persembahan solo bes berkembang dan menjadi tidak asing dalam seni persembahan muzik jazz. Ramai muncul mencipta nama lalu terkenal dengan persembahan solo mereka antaranya seperti Monk Montgomery, Jaco Pastorius, Stanley Clarke, Louis Johnson, John Entwistle, John Deacon dan telah menjadikan kemahiran bes mereka menjadi ikutan dan sumber inspirasi pemain bes baharu untuk mengikuti jejak langkah mereka.

Beberapa perkara asas yang perlu dikuasai dalam permainan gitar bes sebelum dapat melakukkan persembahan solo adalah antaranya pemahaman mengenai bahagian gitar bes semestinya perlu

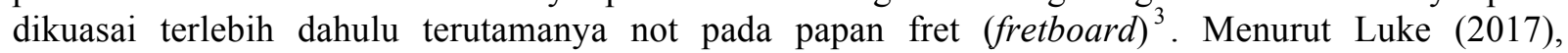
penguasaan not pada papan fret adalah asas penting untuk bermain guitar bes. Pengetahuan mengenai ritma, harmoni, kord dan melodi adalah perkara yang penting untuk bermain gitar bes (Bruce, 2011). Penglibatan tangan kiri dan kanan adalah medium penting dalam bermain alat muzik gitar bes. Latihan yang secukupnya diperlukan bagi kedua tangan dalam memastikan penghasilan bunyi yang baik.

\footnotetext{
${ }^{1}$ Intermediate Electric Bass, The Complete Electric Bass Method oleh David Overthrow, M/s 54 - 64 .

${ }^{2}$ Groove is how several musical practices come together to produce an emphasis on strict chronometric time,

Groove: An Aesthetic of Measure Time, Mark Abel. M/s 12

${ }^{3}$ Papan fret pada leher gitar bass
} 
Pengetahuan setiap not pada papan jari yang mempunyai fret pada bes elektrik serta posisi seharusnya dikuasai untuk kelancaran semasa persembahan solo bes.

Dalam kajian ini, penumpuan dituju khas kepada tangan kiri untuk meneroka bentuk-bentuk jari (fingering system) dalam melakukkan persembahan solo bes. Jari kiri adalah antara elemen penting dalam penghasilan bunyi dan tone. Jari kiri boleh dikenali antaranya jari satu (index), jari dua (middle), jari tiga (ring) dan jari empat (pinky). Terdapat dua teknik penjarian yang kini menjadi pilihan pemain bes untuk melakukkan improvisasi seperti teknik satu, dua, tiga, empat (index, middle, ring, pinky) dan teknik satu, dua, empat (index, middle, pinky). Teknik penjarian satu, dua, tiga dan empat adalah penjarian yang sering digunakan untuk eletrik bes manakala penjarian satu, dua dan empat untuk Double bass (Corey, 2011).

Tumpuan kajian ini adalah penyediaan cadangan teknik penjarian yang baru untuk melakukan solo bes iaitu teknik penjarian yang menggunakan jari satu, dua dan tiga atau dikenali sebagai jari Index, Middle dan Ring (IMR). Dalam kajian ini, singkatan nama IMR digunakan untuk mewakili cadangan teknik penjarian tersebut dan bertujuan memudahkan proses penerangan.

Dalam permainan elektrik bass, Shifting atau peralihan jari penting apabila ingin melakukkan persembahan solo bes. Jari perlu bergerak dalam keadaan tersusun tanpa tersekat agar perancangan melodi atau idea ritma yang ingin dicipta akan terhasil. Apabila shifting tidak dapat dirangka dengan baik, ini akan mencetuskan penghasilan melodi atau idea yang tidak kemas dan seterusnya menyebabkan pergerakan not tidak dapat diserasikan dengan tempo muzik. Penjarian yang yang tidak teratur akan menyebabkan penghasilan bunyi yang tidak konsisten.

Selain itu, teknik bending atau melentur tali merupakan salah satu teknik yang kini digunapakai semasa persembahan solo bes yang mana disebabkan keunikan fungsi dan kesan dingin pada penghasilan. Banyak pemain bass terkemuka yang menggunakan teknik ini semasa persembahan solo antaranya adalah Jaco Pastorius, Larry Graham, Victor Wooten dan Marcus Miller.

Mengartikulasikan teknik hammer on, pull off, dan trill (mengetar) juga pencetus ke arah persembahan solo bes yang lebih menarik dan berjaya disamping memberi kelancaran mengerakkan solo bes.

\section{Metod Kajian}

Projek pilot merupakan ujian pra atau proses percubaan intrumen kajian (Baker 1994). Menurut Teijlingen dan Hundley (2001), projek pilot juga mencetuskan data kemungkinan yang boleh dianalisis.

Metodologi ini bertujuan mendapatkan data melalui keratan notasi yang dicipta seperti etude (Notasi 1). Keratan notasi ini dicipta mengikut kesesuaian inti pati kajian dan dicaturkan kesemuanya pada satu frasa notasi solo bes yang panjang sekitar 10 bar. Elemen yang ditampilkan adalah hasil rujukan 4 solo pemain bes terkemuka yang telah ditranskrip. Peralihan dan perlintasan jari adalah di ambil hasil dari solo bes Tom Kenedy dan Geddy Lee. Bending atau Perlenturan not adalah merujuk kepada solo bes Jaco Pastorius. Artikulasi Hammer On, Pull Off dan Trill adalah melalui Jeff Andrew dan Geddy Lee.

Kaedah ini telah melibatkan beberapa pemain bes dari kalangan pelajar diperingkat Diploma dan Sarjana Muda. Pemilihan pemain bes ini dipilih mengikut syarat kaedah yang telah ditetapkan antara syarat pemilihan bagi kaedah ini adalah 1), Kebolehan membaca dan memainkan keratan notasi atau etude yang telah dicipta. Syarat yang seterusnya 2), pemain bes atau pelajar semestinya boleh melakukan persembahan solo bes. Tidak menegaskan pemain bes itu kena mahir mempersembahkan solo bes, asalkan mereka boleh sudah mencukupi. Ini kerana fokus kajian ini adalah pada penjarian tangan kiri melakukan persembahan solo bes pada fret bes terhadap kelajuan peralihan dan perlintasan jari, teknik bending dan artikulasi teknik yang lain. 
DOI: https://doi.org/10.47405/mjssh.v5i5.421

Projek pilot ini telah dijalankan di bilik Kristal, Universiti Malaysia Sabah (UMS). Seramai lapan pelajar telah dipilih dan masing-masing diminta untuk membawa elektrik bes sendiri. Kesemua pelajar diberikan satu keratan notasi (etude) yang mempunyai 10 bar (Notasi 1). Etude yang bertujuan mendapatkan penjarian yang boleh membantu melancarkan persembahan bes solo elektrik tersebut mengandungi komponan pergerakan alihan dan lintasan, teknik bending dan artikulasi teknik hammer on, pull off dan trill.

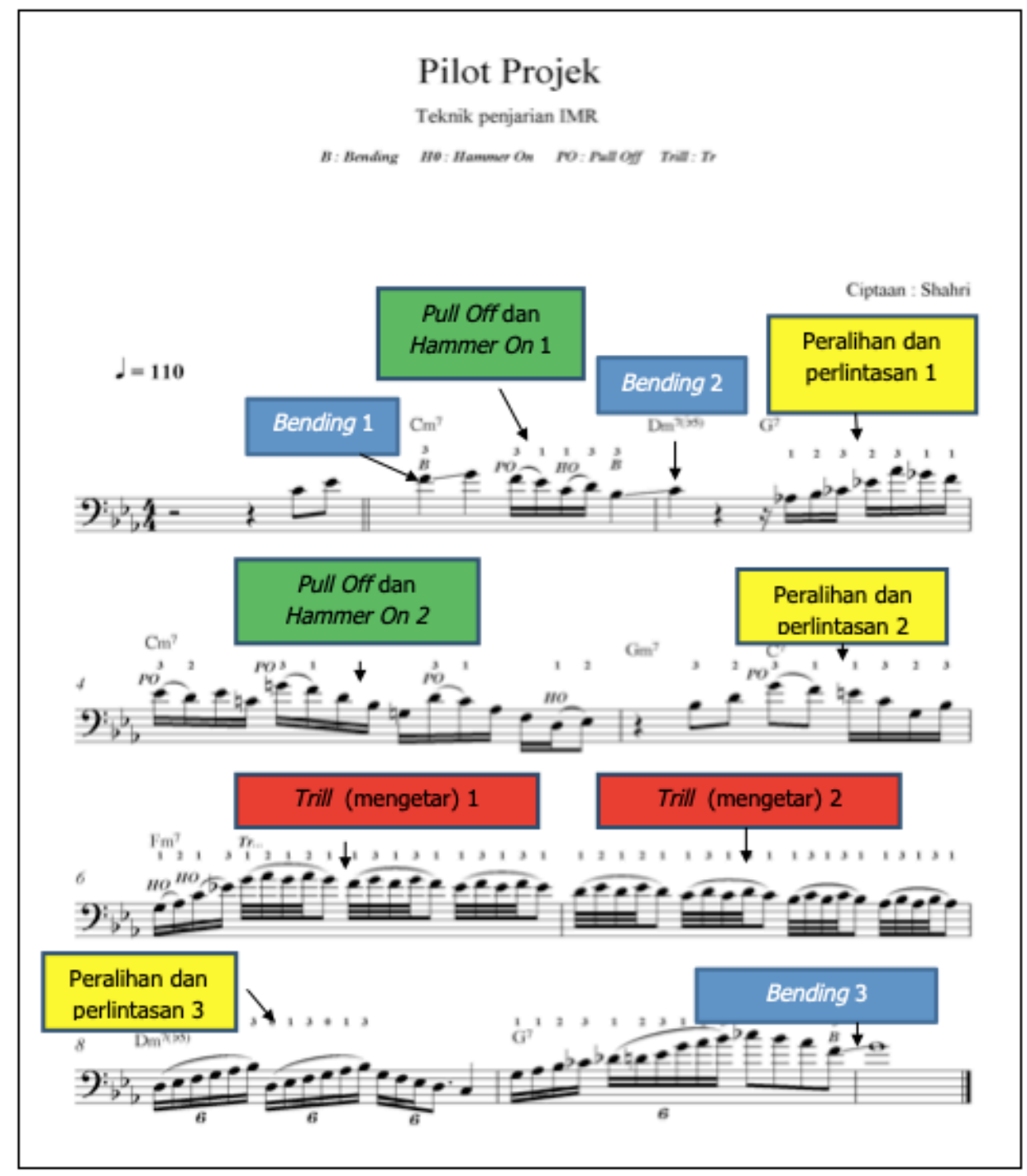

Notasi 1: Keratan notasi (etude)

Penilaian dan pengukuran permarkahan bagi projek pilot ini telah menggunakan penjadualan sebuah rubrik mengikut metod pencetusan rubrik oleh Dannelle dan Antonia dari buku mereka yang berjudul "Introduction of Rubrics" (Jadual 1).

Jadual 1: Rubrik Penilaian Projek Pilot Pada Satu Keratan Etude

\begin{tabular}{lllll}
\hline Kriteria (K) & Frasa 1 & Frasa 2 & Frasa 3 & $\begin{array}{l}\text { Jumlah } \\
\text { Keseluruhan Frasa }\end{array}$ \\
\hline $\begin{array}{l}\text { Peralihan } \\
\text { perlintasan }\end{array}$ & dan & $\begin{array}{l}\text { Dimainkan tanpa } \\
\text { kesilapan not }\end{array}$ & $\begin{array}{l}\text { Dimainkan tanpa } \\
\text { kesilapan not }\end{array}$ & $\begin{array}{l}\text { Dimainkan tanpa } \\
\text { kesilapan not }\end{array}$ \\
Lenturan & $\begin{array}{l}\text { Mengikut tempo } \\
\text { Dimainkan tanpa } \\
\text { kesilapan not }\end{array}$ & $\begin{array}{l}\text { Mengikut tempo } \\
\text { Dimainkan tanpa } \\
\text { kesilapan not }\end{array}$ & $\begin{array}{l}\text { Mengikut tempo } \\
\text { Dimainkan tanpa } \\
\text { kesilapan not }\end{array}$ & 3 \\
\hline
\end{tabular}




\begin{tabular}{|c|c|c|c|c|}
\hline Trill & $\begin{array}{l}\text { Mengikut tempo } \\
\text { Dimainkan tanpa } \\
\text { kesilapan not }\end{array}$ & $\begin{array}{l}\text { Mengikut tempo } \\
\text { Dimainkan tanpa } \\
\text { kesilapan not }\end{array}$ & Mengikut tempo & 2 \\
\hline $\begin{array}{l}\text { Hammer On, Pull } \\
\text { Off }\end{array}$ & $\begin{array}{l}\text { Mengikut tempo } \\
\text { Dimainkan tanpa } \\
\text { kesilapan not }\end{array}$ & $\begin{array}{l}\text { Mengikut tempo } \\
\text { Dimainkan tanpa } \\
\text { kesilapan not }\end{array}$ & & 2 \\
\hline $\begin{array}{l}\text { Jumlah } \\
\text { keseluruhan }\end{array}$ & $\begin{array}{l}\text { Mengikut tempo } \\
\text { * Sekiranya kedua } \\
\text { dua komponen } \\
\text { tidak didapat } \\
\text { dilaksanakan } \\
\text { dianggap tidak } \\
\text { Berjaya }\end{array}$ & $\begin{array}{l}\text { Mengikut tempo } \\
\text { *Sekiranya kedua } \\
\text { dua komponen } \\
\text { tidak didapat } \\
\text { dilaksanakan } \\
\text { dianggap tidak } \\
\text { berjaya }\end{array}$ & $\begin{array}{l}\text { *Sekiranya kedua } \\
\text { dua komponen } \\
\text { tidak didapat } \\
\text { dilaksanakan } \\
\text { dianggap tidak } \\
\text { berjaya }\end{array}$ & 10 \\
\hline
\end{tabular}

Pelajar tersebut diberikan masa untuk berlatih memainkan etude tersebut secara bersendirian, secara bebas mengikut penjarian masing-masing. Masa yang telah diberikan adalah selama 1 jam dan pelajar diminta memainkan sebanyak 5 kali pusingan. Pengiraan markah 1 hingga 10 telah diberi bagi setiap pusingan. Ukuran 10 ini adalah merujuk kepada kumpulan frasa penting iaitu tiga frasa bagi peralihan dan perlintasan, dua frasa bagi teknik trill, dua frasa bagi teknik pull off dan hammer on dan tiga frasa bagi teknik lenturan (Notasi 1). Respon dari pelajar itu sendiri diambil mengenai pengalaman dan pendapat memainkan etude tersebut. Seterusnya mereka diminta memainkan etude itu semula menggunakan sistem penjarian IMR yang tersedia ditulis. Masa yang sama iaitu selama 1 jam telah diberikan untuk melatih etude yang sama menggunakan penjarian IMR. Pengiraan markah 1 hingga 10 telah diberi bagi setiap pusingan. Respon dari pelajar berkenaan pengalaman memainkan etude tersebut menggunakan penjarian IMR dicatat dan didokumentasikan.

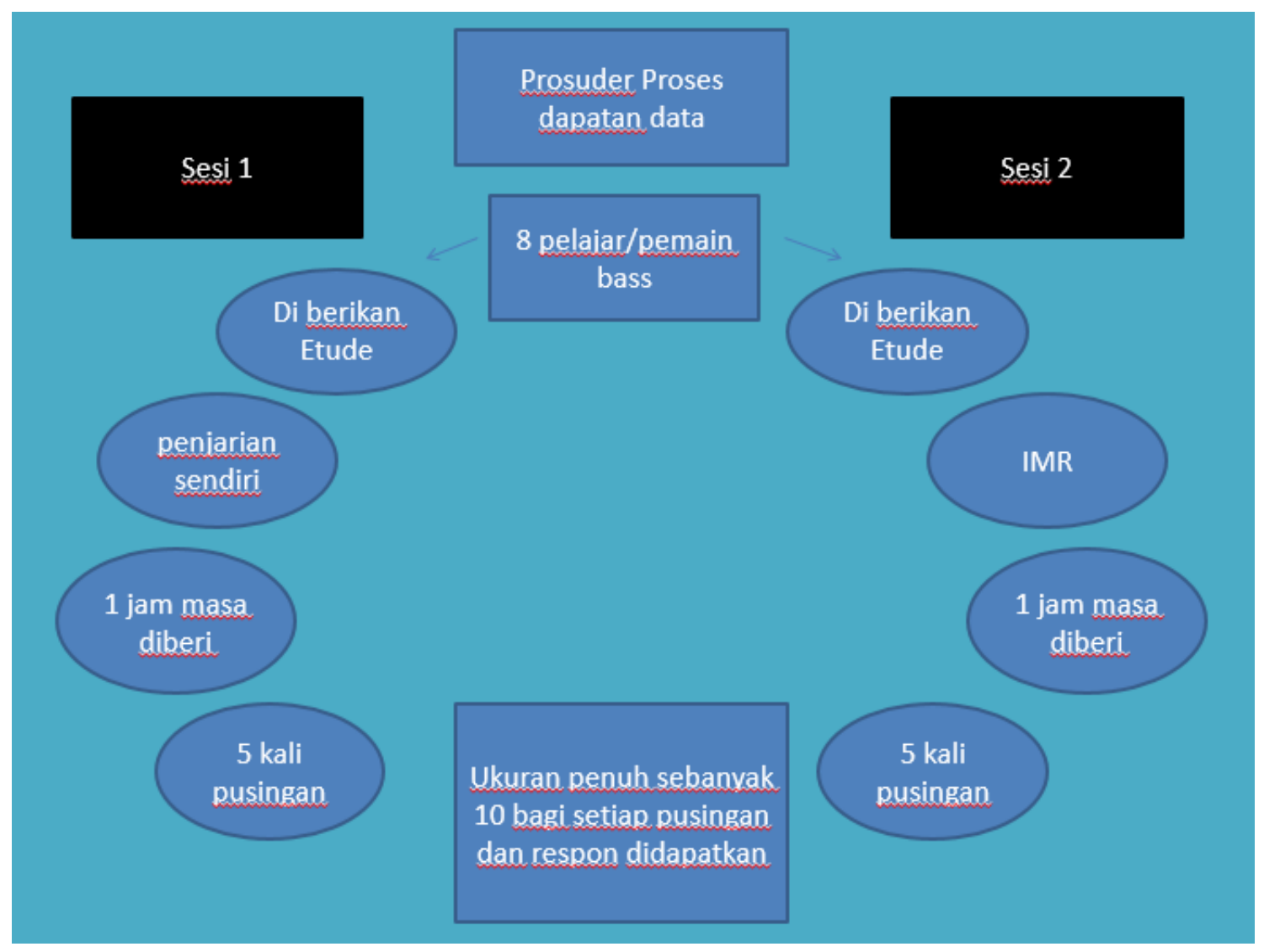

Rajah 1: Prosedur Proses Dapatan Data Projek Pilot 


\section{Dapatan Data Pilot Projek Melalui Pusingan}

Pengiraan markah 1 hingga 10 telah diberi bagi setiap pusingan. Ukuran 10 ini adalah merujuk kepada kumpulan frasa penting iaitu tiga frasa bagi peralihan dan perlintasan, dua frasa bagi teknik trill, dua frasa bagi teknik pull off dan hammer on dan tiga frasa bagi teknik lenturan (Notasi 1). Rubrik penilaian bagi projek ini juga telah dibuat bagi menyatakan bagaimana penilaian diberi (Rajah 2).

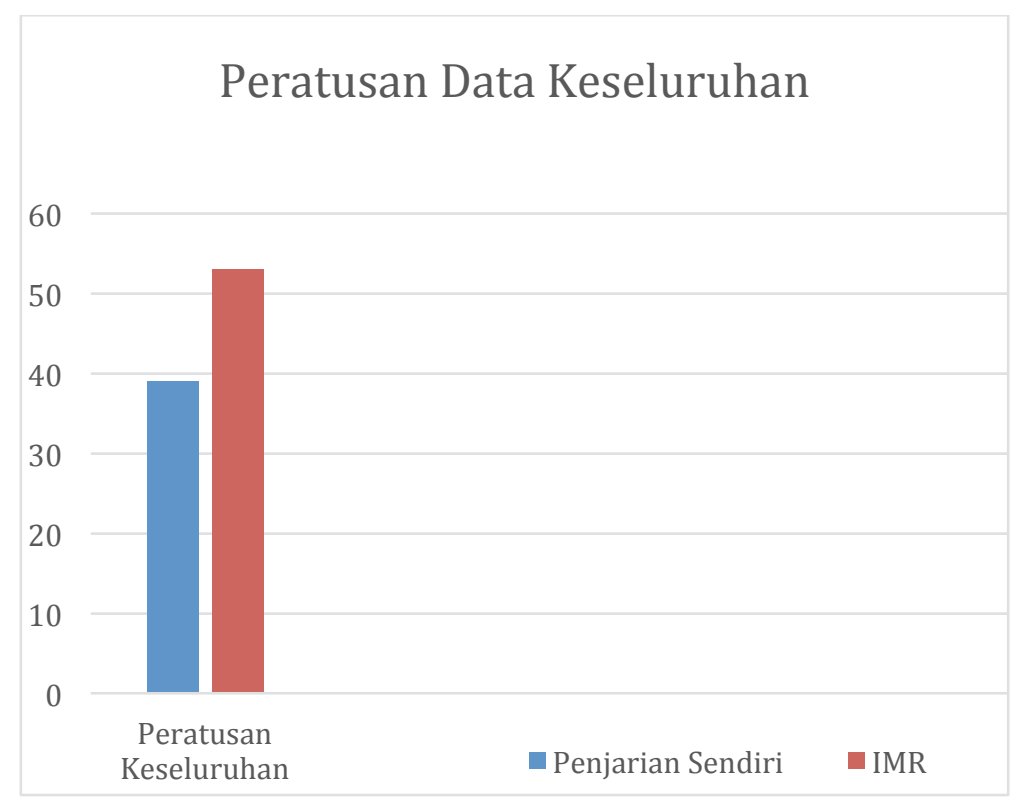

Rajah 2: Rubrik penilaian

Merujuk kepada Notasi 1, keratan notasi sebuah etude yang dicipta khas untuk kajian teknik penjarian IMR dimana penglibatan seperti 3 peralihan dan perlintasan, 3 lenturan, 2 hammer on, pull off dan 2 trill. Keratan notasi ini adalah sebanyak 10 bar dan tempo yang digunakan adalah sekitar 110 sehingga $130 \mathrm{BPM}$.

Penggunaan singkatan teknik melentur (B), Hammer on (HO), Pull off (PO) dan trill (Tr) adalah bertujuan memudahkan responden yang terlibat dalam pilot projek ini mengenalpasti di manakah penggunaan teknik tersebut digunakan sebelum memulakan latihan. Selain itu, peletakkan nombor 1 (Index), 2 (middle) dan 3 (ring) telah disediakan pada setiap notasi yang ingin perlu digunakan dalam teknik penjarian IMR.

Terdapat 8 responden (pelajar) yang terlibat dan mereka mewakili 3 institusi pengajian di Kota Kinabalu, Sabah iaitu Universiti Malaysia Sabah (UMS), Eastern College (EC) dan Sabah Instituite of Art (SIA). Kesemua responden ini adalah pelajar yang mengambil alat muzik elektrik bes sebagai alat muzik utama dan dipilih mengikut krateria yang bertepatan dengan syarat projek pilot ini.

Jadual 2 di bawah adalah nama responden, profisen dan kod yang diberi kepada setiap responden (pelajar) yang dinilai. Kod ini direka untuk mewakili setiap responden seperti pelajar 1 sebagai S1, pelajar dua S2 dan seterusnya hingga pelajar lapan S8.

Jadual 2: Penama, profisen dan pengkodan untuk projek Pilot

\begin{tabular}{lll}
\hline Nama Pelajar & Status/Institusi & Kod \\
\hline Shahzrol & Pelajar UMS & S1 \\
Evv Vanzhoe & Pelajar EC & S2 \\
\hline
\end{tabular}


DOI: https://doi.org/10.47405/mjssh.v5i5.421

\begin{tabular}{lll}
\hline Jeiren & Pelajar EC & S3 \\
Sahari Talami & Pelajar UMS & S4 \\
Juergen Jekulon & Pelajar EC & S5 \\
Raynold & Pelajar UMS & S6 \\
Vie Everrollah & Pelajar EC & S7 \\
Jebrew Lystra & Pelajar SIA & S8 \\
\hline
\end{tabular}

\section{Dapatan Kajian}

\section{Data Kelajuan Penjarian Melalui Peralihan dan Perlintasan Not}

Melalui projek pilot ini, tiga frasa notasi telah disediakan khusus untuk peralihan dan lintasan menggunakan penjarian IMR untuk memberi kelajuan dalam persembahan solo bes iaitu frasa pertama pada bar 3 bermula pada bit ke- tiga dan ke- empat serta frasa kedua pada bar 5 dan frasa ketiga pada bar 8 .

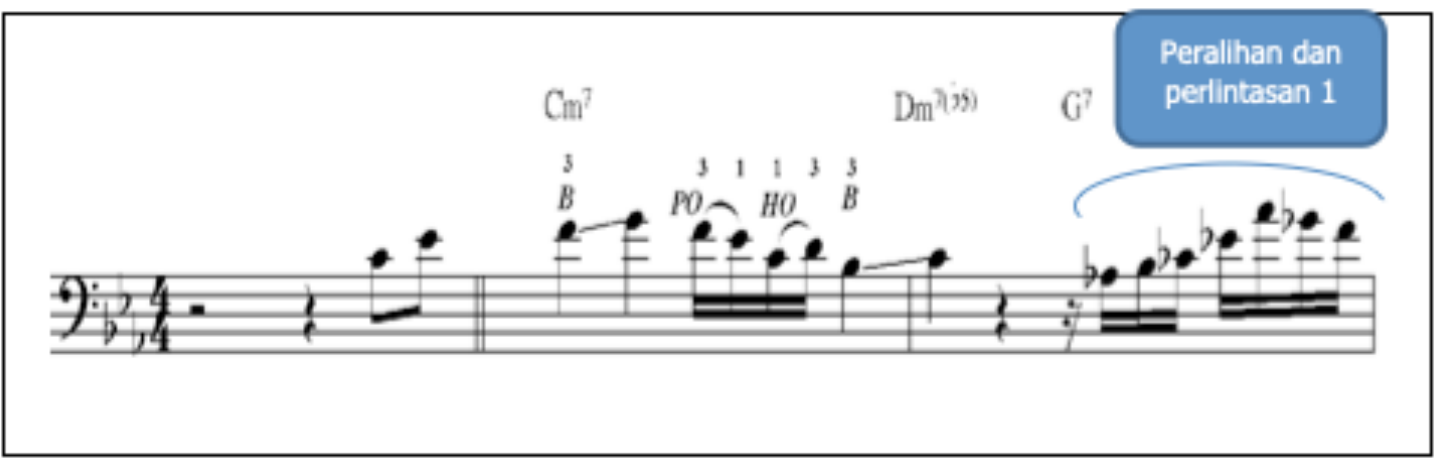

Notasi 2: Peralihan dan perlintasan pertama pada bar 3

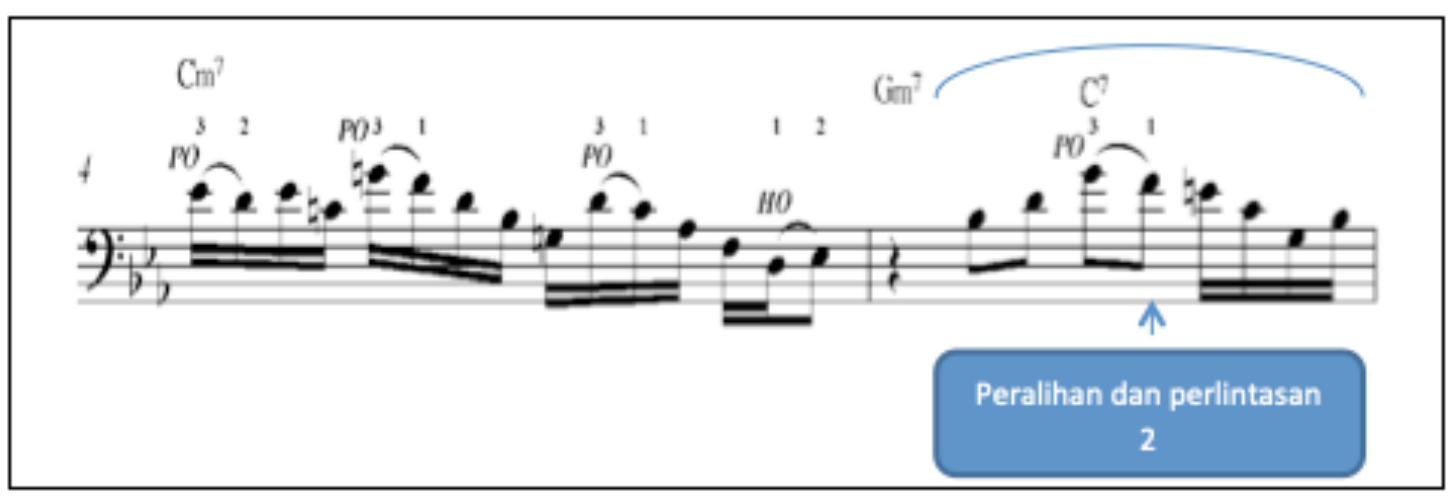

Notasi 3: Peralihan dan perlintasan kedua pada bar 5

Pelajar telah diberikan taklimat dan prosuder perlaksanaan projek pilot sebelum memulakan permainan. Projek pilot ini dimulakan dengan bahagian peralihan dan lintasan menggunakan teknik penjarian sendiri dan IMR. Tiga frasa disediakan yang memfokuskan bahagian peralihan dan lintasan, dua frasa dapat dirujuk pada Notasi 2 dan Notasi 3. 
Sebelum tugasan dimulakan, responden (pelajar) diminta memainkan notasi tersebut menggunakan penjarian masing - masing dan masa telah diberikan untuk melatihnya terlebih dahulu. Seterusnya responden diminta memainkan keratan notasi tersebut. Data yang diperolehi didokumentasikan atau dicatat melalui pemerhatian dan respon lisan dari responden itu sendiri. Menurut responden S1, penjarian menjadi tegang dan susah apabila ingin mempercepatkan pergerakan jari pada peralihan dan perlintasan 2 dari keratan notasi 15. Menurut responden S3, amat susah untuk mengerakan jari pada Notasi 14 dari not Eb melintas ke Ab, manakala responden S4 menyatakan kesukaran untuk memainkan Notasi 15 secara terus dan laju biarpun ia telah berlatih berberapa kali dengan tempo yang perlahan. Didapati penggunaan penjarian pelajar memiliki masalah dalam mengerakkan notasi tersebut.

Responden seterusnya diminta untuk memainkan keratan notasi menggunakan teknik penjarian IMR dimana nombor penjarian tertera pada notasi itu (Rujuk lampiran A). Nombor tersebut mewakili jari yang perlu digunakan, dan ditegaskan untuk mencondongkan not yang tertentu dengan jari yang tertentu. Responden diberi masa untuk melatihnya sebelum data diambil. Setelah mereka memainkan keratan notasi tersebut dan seterusnya data diperoleh bagi mendapatkan perbandingan dengan penjarian yang pelajar gunakan sebelum menggunakan teknik penjarian IMR. Dari permainan kedua keratan ini didapati responden dapat merasakan keselesaan dalam mengerakkan Notasi 2 dan 3 dengan menggunakan teknik penjarian IMR, Menurut responden S1, pergerakkan penjarian menjadi lancar apabila melakukkan notasi dari keratan notasi 2 sekali dengan tempo laju. Menurut responden S5, jari dapat menjangkau denagn senangnya not ke not yang disediakan. Menurut responden S7, beliau merasakan kordinasi tangan kiri dan kanan dapat merasa keserasian dalam melakukan permainan dengan jelas dan tepat.

\section{Teknik Melentur}

Dalam notasi ini juga, teknik melentur telah diselitkan bagi mendapatkan data penjarian IMR. Pada Notasi 4 dan Notasi 5, teknik melentur dapat diperhatikan dengan singakatan 'B'.

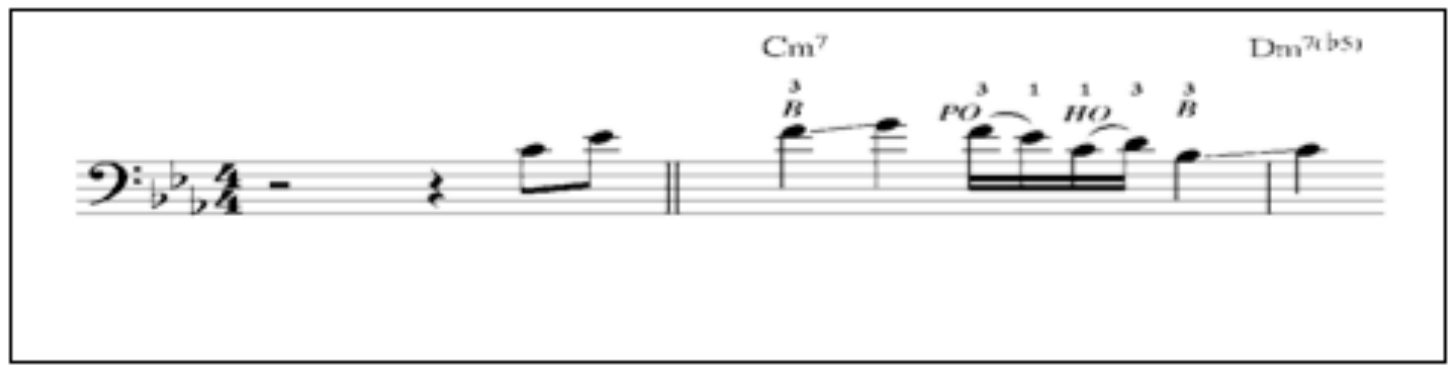

Notasi 4: Lenturan pada bar 1

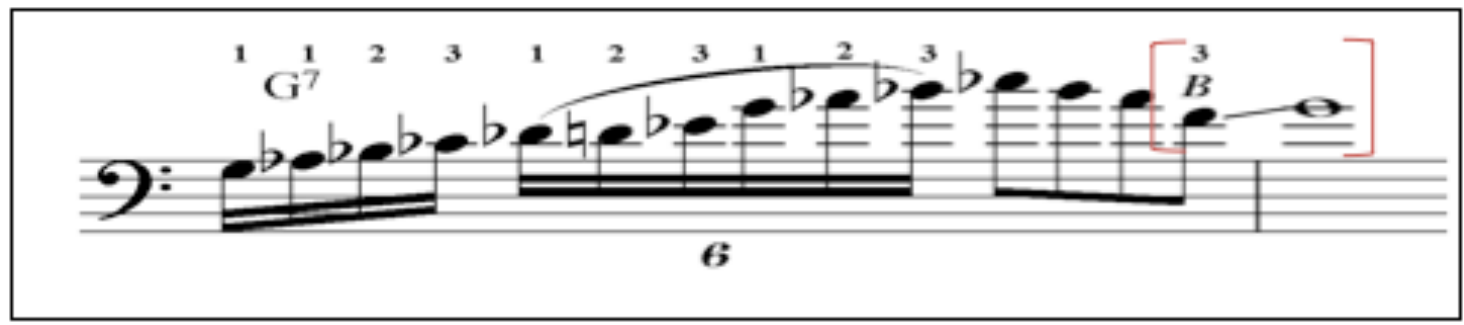

Notasi 5: Lenturan pada bar 10

Merujuk pada Notasi 4 dan Notasi 5 di atas adalah keratan dari projek pilot yang menampilkan teknik bending. Pada bahagian ini, prosuder yang sama telah diminta untuk memainkan lenturan ini. Selepas responden memainkan petikan ini menggunakan penjarian masing - masing, didapati ada persamaan dengan teknik penjarian IMR yang mana responden menggunakan jari 2 dan 3 untuk melakukkannya. Menurut responden S3, terdapat kesukaran untuk melakukan lenturan 1 ton. Menurut responden S5, 
pemasalahan mengatur jari adalah satu-satunya punca kelemahan dalam meneluarkan lenturan yang sempurna. kebanyakkan responden ini menggunakan penjarian IMR dalam melakukkan lenturan tanpa disedari.

Setelah responden ini diberi masa untuk berlatih dan memainkan notasi tersebut, didapati mereka merasa sedikit keselesaan dalam memainkan lenturan tersebut dan pelajar juga menyatakan terdapat kesukaran untuk melenturkan not apabila melibatkan 1 ton lenturan menarik. Oleh itu, cara melentur menaik 1 ton dilakukkan dengan melibatkan peralihan not. Sebagai contoh pada notasi bar 1 pelenturan dari not $\mathrm{F}$ ke not $\mathrm{G}$ adalah berjarak 1 ton, pelenturan akan dilakukan menggunakan jari 3 dibantu oleh jari 1 dan 2 dan seterusnya not $\mathrm{F}$ akan dialihkan ke not $\mathrm{F} \#$ lalu dilenturan menaik secara terus ke not $\mathrm{G}$. Ini telah dicuba oleh pelajar dan kesemua pelajar merasakan kemampuan dan kesenangan dalam melakukannya.

\section{Hammer On dan Pull Off}

Melalui notasi 6, dapat dilihat penglibatan artikulasi teknik Hammer on dan Pull off pada notasi yang disediakan. Jika dilihat kedua teknik ini boleh memberi kesinambungan dalam penghasilan melodi yang berbentuk urutan dan pengulangan not. Ini akan mempengaruhi kemampuan jari untuk melakukkan penghasilan not atau persembahan solo bes khususnya apabila melibatkan tempo laju.

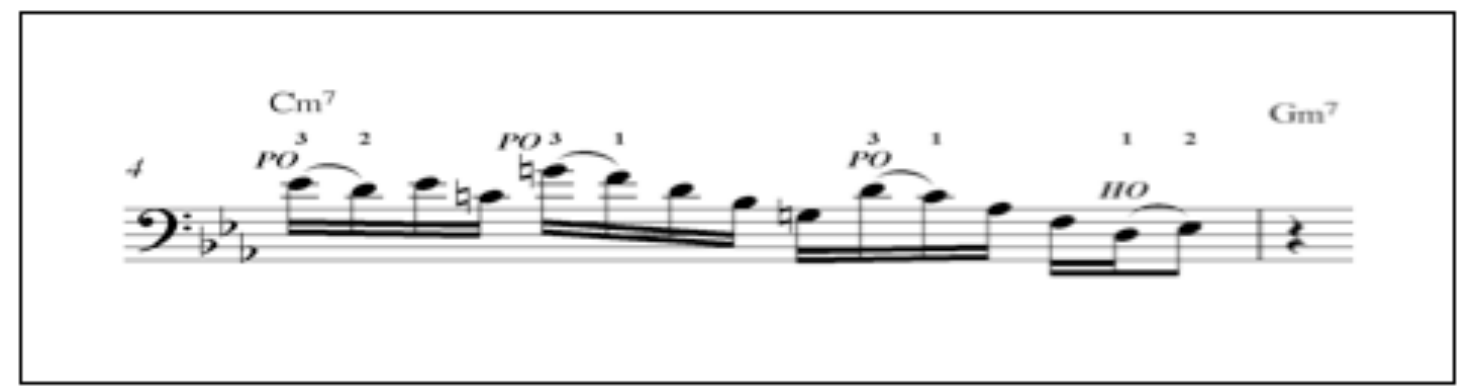

Notasi 6: Hammer on dan Pull Off

Menurut responden S6, beliau mendapat kesukaran melakukan pull off pada 2 not pertama dengan menggunakan jari 4 dan 3. Menurut S8, jari mengalami kesukaran untuk melakukan dan menghubungkan not apabila melibatkan pull off dan hammer on. Selepas itu, pelajar diminta untuk melakukan notasi dengan menggunakan teknik penjarian IMR yang telah disediakan. Pelajar juga merasakan kesenangan untuk melakukkan teknik ini pada notasi tersebut dan juga mampu melakukannya pada tempo laju.

\section{Trill}

Merujuk pada Notasi 7, sebuah frasa trill telah disediakan dengan pergerakkan not secara menurun. Bermula dari bar 6 sehingga bar 7, trill ini bergerak aktif dan laju tanpa berhenti. Ini adalah salah satu frasa yang mencabar yang mana semestinya dalam penghasilannya memerlukan pemilihan penjarian yang kuat, tangkas dan cekap.

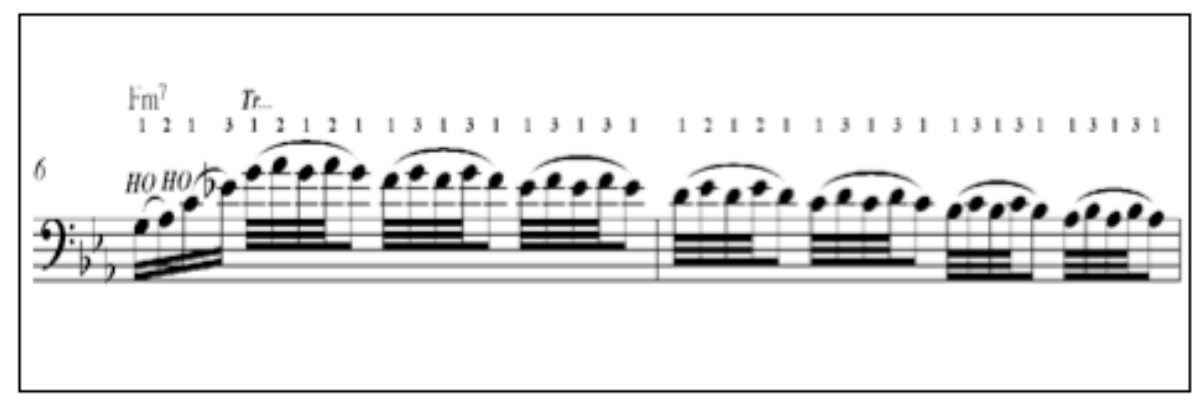

Notasi 7: Trill 
Responden telah diminta untuk melakukan pergerakan trill dari keratan notasi yang disediakan dengan menggunakan penjarian sendiri. Responden juga telah diberi masa untuk melatihnya terlebih dahulu. Dari aktiviti ini, didapati responden mengalami kesukaran untuk memainkan frasa trill Notasi 7 kerana kebanyakkan dari mereka menggunakan penglibatan jari 4. Menurut responden S2, amat sukar untuk melakukan trill dengan penglibatan jari 4 dalam tempo yang laju. Menurut S4, kecepatan jari untuk melakukkan trill ini sangat terganggu untuk menghubungkan pemilihan jari dan menyebabkan jari menjadi bercelaru. Setelah itu, responden diminta untuk menggunakan penjarian IMR yang telah disediakan pada keratan Etude tersebut. Prosuder yang sama telah dilakukan oleh responden sebelum menyempurnakan frasa tersebut.

Selepas keratan tersebut dimainkan oleh responden menggunakan penjarian IMR, sebilangan besar dari mereka mempersetujui penggunaan penjarian IMR ini memberi kelancaran pada jari mereka untuk melakukkan trill dalam tempoh yang laju. Menurut responden S4, penjarian ini membantu kelancaran penjarian untuk bergerak dan menekan fret tersebut, manakala responden S1, ini memudahkan pergerakan jari disebabkan jarak trill ini adalah ton dan semiton.

\section{Dapatan Kajian}

\section{Dapatan Data Melalui Pusingan}

Pengiraan markah 1 hingga 10 telah diberi bagi setiap pusingan. Ukuran 10 ini adalah merujuk kepada kumpulan frasa penting iaitu tiga frasa bagi peralihan dan perlintasan, dua frasa bagi teknik trill, dua frasa bagi teknik pull off dan hammer on dan tiga frasa bagi teknik lenturan. Rubrik penilian bagi projek ini juga telah dibuat bagi menyatakan bagaimana penilaian diberi.

\section{Dapatan Melalui Penjarian Sendiri}

Jadual 3 merupakan data dapatan projek pilot melalui tiga peralihan dan perlintasan dengan menggunakan penjarian sendiri. Pelajar telah memainkan etude projek pilot sebanyak lima kali pusingan. Mata bagi setiap pusingan diambil dan dijadualkan. Jumlah diterima setelah mata lima pusingan dikumpulkan.

Jadual 3: Data dapatan melalui peralihan dan perlintasan menggunakan penjarian sendiri

\begin{tabular}{llllllll}
\hline $\begin{array}{l}\text { Pemain } \\
\text { bass /S }\end{array}$ & $\begin{array}{l}\text { Frasa } \\
\text { notasi }\end{array}$ & $\begin{array}{l}\text { Pusingan } \\
1\end{array}$ & $\begin{array}{l}\text { Pusingan } \\
2\end{array}$ & $\begin{array}{l}\text { Pusingan } \\
(/ 3)\end{array}$ & $\begin{array}{l}\text { Pusingan } \\
4\end{array}$ & $\begin{array}{l}\text { Pusingan } \\
(/ 3)\end{array}$ & $\begin{array}{l}\text { Jumlah } \\
(/ 3)\end{array}$ \\
\hline S1 & Peralihan & 1 & 1 & 2 & 2 & 3 & \\
S2 & Peralihan & 0 & 1 & 1 & 2 & 2 & 6 \\
S3 & Peralihan & 0 & 0 & 1 & 2 & 2 & 5 \\
S4 & Peralihan & 1 & 1 & 2 & 2 & 3 & 9 \\
S5 & Peralihan & 0 & 1 & 1 & 2 & 3 & 7 \\
S6 & Peralihan & 0 & 0 & 0 & 1 & 1 & 2 \\
S7 & Peralihan & 1 & 1 & 2 & 3 & 3 & 10 \\
S8 & Peralihan & 0 & 0 & 1 & 2 & 3 & 6 \\
\hline
\end{tabular}

Jadual 4 merupakan data dapatan projek pilot melalui dua Trill menggunakan penjarian sendiri. Pelajar telah menggunakan penjarian sendiri memainkan etude projek pilot sebanyak lima kali pusingan. Mata bagi setiap pusingan di ambil dan dijadualkan. Jumlah diterima setelah mata lima pusingan dikumpulkan. 
DOI: https://doi.org/10.47405/mjssh.v5i5.421

Jadual 4: Data dapatan melalui Trill menggunakanpenjarian sendiri

\begin{tabular}{|c|c|c|c|c|c|c|c|}
\hline $\begin{array}{l}\text { Pemain } \\
\text { bass /S }\end{array}$ & $\begin{array}{l}\text { Frasa } \\
\text { notasi }\end{array}$ & $\begin{array}{l}\text { Pusingan } \\
1 \\
(/ 2)\end{array}$ & $\begin{array}{l}\text { Pusingan } \\
2 \\
\text { (/2) }\end{array}$ & $\begin{array}{l}\text { Pusingan } \\
\mathbf{3} \\
(/ 2)\end{array}$ & $\begin{array}{l}\text { Pusingan } \\
4 \\
(/ 2)\end{array}$ & $\begin{array}{l}\text { Pusingan } \\
5 \\
(/ 2)\end{array}$ & Jumlah \\
\hline $\mathrm{S} 1$ & Trill (tr) & 0 & 1 & 1 & 2 & 2 & 6 \\
\hline $\mathrm{S} 2$ & Trill (tr) & 0 & 0 & 1 & 1 & 2 & 4 \\
\hline S3 & Trill (tr) & 0 & 0 & 0 & 1 & 1 & 2 \\
\hline S4 & Trill (tr) & 1 & 1 & 2 & 2 & 2 & 8 \\
\hline S5 & Trill (tr) & 1 & 1 & 1 & 2 & 2 & 8 \\
\hline S6 & Trill (tr) & 0 & 0 & 0 & 1 & 1 & 2 \\
\hline S7 & Trill (tr) & 1 & 1 & 2 & 2 & 2 & 8 \\
\hline S8 & Trill (tr) & 0 & 1 & 1 & 2 & 2 & 6 \\
\hline
\end{tabular}

Jadual 5 merupakan data dapatan projek pilot melalui tiga lenturan menggunakan penjarian sendiri. Pelajar telah menggunakan penjarian sendiri memainkan etude projek pilot sebanyak lima kali pusingan. Mata bagi setiap pusingan di ambil dan dijadualkan. Jumlah diterima setelah mata lima pusingan dikumpulkan.

Jadual 5: Data dapatan melalui melentur menggunakan penjarian sendiri

\begin{tabular}{llllllll}
\hline $\begin{array}{l}\text { Pemain } \\
\text { bass } / \mathbf{S}\end{array}$ & $\begin{array}{l}\text { Frasa } \\
\text { notasi }\end{array}$ & $\begin{array}{l}\text { Pusingan } \\
\mathbf{1}\end{array}$ & $\begin{array}{l}\text { Pusingan } \\
\mathbf{2}\end{array}$ & $\begin{array}{l}\text { Pusingan } \\
\mathbf{3}\end{array}$ & $\begin{array}{l}\text { Pusingan } \\
\mathbf{4}\end{array}$ & $\begin{array}{l}\text { Pusingan } \\
\mathbf{5}\end{array}$ & Jumlah \\
& & $\mathbf{( / 3 )}$ & $\mathbf{( / 3 )}$ & $\mathbf{( / 3 )}$ & \\
\hline S1 & Menlentur & 0 & 0 & 1 & 1 & 1 & 3 \\
S2 & Menlentur & 0 & 1 & 1 & 2 & 2 & 6 \\
S3 & Menlentur & 0 & 0 & 0 & 0 & 1 & 1 \\
S4 & Menlentur & 0 & 0 & 1 & 1 & 1 & 3 \\
S5 & Menlentur & 0 & 0 & 0 & 1 & 1 & 2 \\
S6 & Menlentur & 0 & 0 & 0 & 0 & 0 & 0 \\
S7 & Menlentur & 0 & 0 & 1 & 1 & 1 & 3 \\
S8 & Menlentur & 0 & 0 & 1 & 1 & 2 & 4 \\
\hline
\end{tabular}

Jadual 6 merupakan data dapatan projek pilot melalui dua pull off dan hammer on menggunakan penjarian sendiri. Pelajar telah menggunakan penjarian sendiri memainkan etude projek pilot sebanyak lima kali pusingan. Mata bagi setiap pusingan di ambil dan dijadualkan. Jumlah diterima setelah mata lima pusingan dikumpulkan.

Jadual 6: Data dapatan melalui Pull Off dan Hammer On menggunakan penjarian sendiri

\begin{tabular}{llllllll}
\hline $\begin{array}{l}\text { Pemain } \\
\text { bass /S }\end{array}$ & $\begin{array}{c}\text { Frasa } \\
\text { notasi }\end{array}$ & $\begin{array}{c}\text { Pusingan } \\
\mathbf{1} \\
(/ \mathbf{2})\end{array}$ & $\begin{array}{c}\text { Pusingan } \\
\mathbf{2} \\
(/ \mathbf{2})\end{array}$ & $\begin{array}{c}\text { Pusingan } \\
\mathbf{3} \\
(/ \mathbf{2})\end{array}$ & $\begin{array}{c}\text { Pusingan } \\
\mathbf{4} \\
(\mathbf{/ 2})\end{array}$ & $\begin{array}{c}\text { Pusingan } \\
\mathbf{5} \\
(\mathbf{/ 2})\end{array}$ & Jumlah \\
\hline S1 & $P O, H O$ & 0 & 0 & 1 & 1 & 2 & 4 \\
S2 & $P O, H O$ & 0 & 1 & 1 & 1 & 2 & 5 \\
S3 & $P O, H O$ & 0 & 0 & 0 & 1 & 1 & 2 \\
S4 & $P O, H O$ & 0 & 1 & 1 & 2 & 2 & 6 \\
S5 & $P O, H O$ & 0 & 0 & 1 & 1 & 2 & 4 \\
S6 & $P O, H O$ & 0 & 0 & 0 & 1 & 1 & 2 \\
S7 & $P O, H O$ & 1 & 1 & 1 & 2 & 2 & 7 \\
S8 & $P O, H O$ & 0 & 0 & 1 & 1 & 2 & 4 \\
\hline
\end{tabular}




\section{Dapatan Melalui IMR}

Jadual 7 merupakan data dapatan projek pilot melalui 3 peralihan dan perlintasan menggunakan penjarian IMR. Pelajar telah menggunakan penjarian IMR memainkan etude projek pilot sebanyak lima kali pusingan. Mata bagi setiap pusingan di ambil dan dijadualkan. Jumlah diterima setelah mata lima pusingan dikumpulkan.

Jadual 7: Data dapatan melalui peralihan dan perlintasan menggunakan IMR

\begin{tabular}{|c|c|c|c|c|c|c|c|}
\hline $\begin{array}{l}\text { Pemain } \\
\text { bass /S }\end{array}$ & $\begin{array}{l}\text { Frasa } \\
\text { notasi }\end{array}$ & $\begin{array}{l}\text { Pusingan } \\
1 \\
(/ 3)\end{array}$ & $\begin{array}{l}\text { Pusingan } \\
2 \\
(/ 3)\end{array}$ & $\begin{array}{l}\text { Pusingan } \\
\mathbf{3} \\
(/ 3)\end{array}$ & $\begin{array}{l}\text { Pusingan } \\
4 \\
(/ 3)\end{array}$ & $\begin{array}{l}\text { Pusingan } \\
5 \\
(/ 3)\end{array}$ & Jumlah \\
\hline S1 & Peralihan & 1 & 1 & 2 & 2 & 3 & 9 \\
\hline $\mathrm{S} 2$ & Peralihan & 0 & 1 & 2 & 2 & 3 & 8 \\
\hline S3 & Peralihan & 0 & 0 & 1 & 2 & 2 & 5 \\
\hline S4 & Peralihan & 1 & 1 & 2 & 3 & 3 & 10 \\
\hline S5 & Peralihan & 0 & 1 & 1 & 2 & 3 & 7 \\
\hline S6 & Peralihan & 0 & 0 & 1 & 1 & 2 & 4 \\
\hline S7 & Peralihan & 1 & 1 & 2 & 3 & 3 & 10 \\
\hline S8 & Peralihan & 0 & 1 & 2 & 2 & 3 & 8 \\
\hline
\end{tabular}

Jadual 8 merupakan data dapatan projek pilot melalui dua Trill menggunakan penjarian IMR. Pelajar telah menggunakan penjarian IMR memainkan etude projek pilot sebanyak lima kali pusingan. Mata bagi setiap pusingan di ambil dan dijadualkan. Jumlah diterima setelah mata lima pusingan dikumpulkan.

Jadual 8: Data dapatan melalui Trill menggunakan IMR

\begin{tabular}{|c|c|c|c|c|c|c|c|}
\hline $\begin{array}{l}\text { Pemain } \\
\text { bass } / \mathrm{S}\end{array}$ & $\begin{array}{l}\text { Frasa } \\
\text { notasi }\end{array}$ & $\begin{array}{l}\text { Pusingan } \\
1 \\
(/ 2)\end{array}$ & $\begin{array}{l}\text { Pusingan } \\
2 \\
(/ 2)\end{array}$ & $\begin{array}{l}\text { Pusingan } \\
3 \\
(/ 2)\end{array}$ & $\begin{array}{l}\text { Pusingan } \\
4 \\
(/ 2)\end{array}$ & $\begin{array}{l}\text { Pusingan } \\
5 \\
(/ 2)\end{array}$ & Jumlah \\
\hline S1 & Trill (tr) & 1 & 1 & 2 & 2 & 2 & 8 \\
\hline S2 & Trill (tr) & 0 & 1 & 2 & 2 & 2 & 7 \\
\hline S3 & Trill (tr) & 0 & 0 & 1 & 1 & 2 & 4 \\
\hline S4 & Trill (tr) & 1 & 1 & 2 & 2 & 2 & 8 \\
\hline S5 & Trill (tr) & 0 & 1 & 2 & 2 & 2 & 7 \\
\hline S6 & Trill (tr) & 0 & 0 & 1 & 1 & 2 & 4 \\
\hline S7 & Trill (tr) & 1 & 1 & 2 & 2 & 2 & 8 \\
\hline S8 & Trill (tr) & 0 & 1 & 2 & 2 & 2 & 7 \\
\hline
\end{tabular}

Jadual 9 merupakan data dapatan projek pilot melalui tiga melentur menggunakan penjarian IMR. Pelajar telah menggunakan IMR memainkan etude projek pilot sebanyak lima kali pusingan. Mata bagi setiap pusingan di ambil dan dijadualkan. Jumlah diterima setelah mata lima pusingan dikumpulkan.

Jadual 9: Data dapatan melalui melentur menggunakan IMR

\begin{tabular}{|c|c|c|c|c|c|c|c|}
\hline $\begin{array}{l}\text { Pemain } \\
\text { bass /S }\end{array}$ & $\begin{array}{l}\text { Frasa } \\
\text { notasi }\end{array}$ & $\begin{array}{l}\text { Pusingan } \\
1 \\
\text { (/3) }\end{array}$ & $\begin{array}{l}\text { Pusingan } \\
2 \\
(/ 3)\end{array}$ & $\begin{array}{l}\text { Pusingan } \\
3 \\
(/ 3)\end{array}$ & $\begin{array}{l}\text { Pusingan } \\
4 \\
(/ 3)\end{array}$ & $\begin{array}{l}\text { Pusingan } \\
5 \\
(/ 3)\end{array}$ & Jumlah \\
\hline S1 & Menlentur & 1 & 1 & 2 & 3 & 3 & 10 \\
\hline $\mathrm{S} 2$ & Menlentur & 1 & 1 & 2 & 3 & 3 & 10 \\
\hline S3 & Menlentur & 0 & 0 & 1 & 2 & 2 & 5 \\
\hline S4 & Menlentur & 1 & 1 & 2 & 3 & 3 & 10 \\
\hline S5 & Menlentur & 1 & 1 & 1 & 2 & 3 & 8 \\
\hline
\end{tabular}


DOI: https://doi.org/10.47405/mjssh.v5i5.421

\begin{tabular}{llllllll}
\hline S6 & Menlentur & 0 & 0 & 1 & 1 & 2 & 4 \\
S7 & Menlentur & 1 & 1 & 2 & 3 & 3 & 10 \\
S8 & Menlentur & 0 & 1 & 2 & 2 & 3 & 8 \\
\hline
\end{tabular}

Jadual 10 merupakan data dapatan projek pilot melalui dua pull off dan hammer on menggunakan penjarian IMR. Pelajar telah menggunakan penjarian IMR memainkan etude projek pilot sebanyak lima kali pusingan. Mata bagi setiap pusingan di ambil dan dijadualkan. Jumlah diterima setelah mata lima pusingan dikumpulkan.

Jadual 10: Data dapatan melalui Pull Off dan Hammer On menggunakan IMR

\begin{tabular}{|c|c|c|c|c|c|c|c|}
\hline $\begin{array}{l}\text { Pemain } \\
\text { bass /S }\end{array}$ & $\begin{array}{l}\text { Frasa } \\
\text { notasi }\end{array}$ & $\begin{array}{l}\text { Pusingan } \\
1 \\
(/ 2)\end{array}$ & $\begin{array}{l}\text { Pusingan } \\
2 \\
(/ 2)\end{array}$ & $\begin{array}{l}\text { Pusingan } \\
3 \\
\text { (/2) }\end{array}$ & $\begin{array}{l}\text { Pusingan } \\
4 \\
(/ 2)\end{array}$ & $\begin{array}{l}\text { Pusingan } \\
5 \\
(/ 2)\end{array}$ & Jumlah \\
\hline S1 & $P O, H O$ & 1 & 1 & 2 & 2 & 2 & 8 \\
\hline $\mathrm{S} 2$ & $P O, H O$ & 1 & 1 & 2 & 2 & 2 & 8 \\
\hline S3 & $P O, H O$ & 0 & 1 & 1 & 2 & 2 & 6 \\
\hline S4 & $P O, H O$ & 1 & 2 & 2 & 2 & 2 & 9 \\
\hline S5 & $P O, H O$ & 1 & 1 & 2 & 2 & 2 & 8 \\
\hline S6 & $P O, H O$ & 0 & 0 & 1 & 1 & 2 & 4 \\
\hline S7 & $P O, H O$ & 1 & 2 & 2 & 2 & 2 & 9 \\
\hline S8 & $P O, H O$ & 0 & 1 & 2 & 2 & 2 & 7 \\
\hline
\end{tabular}

\section{Dapatan Data Penuh}

Jadual 11: Dapatan Data Penuh Melalui Penjarian Sendiri

\begin{tabular}{|c|c|c|c|c|c|c|c|}
\hline $\begin{array}{l}\text { Pemain } \\
\text { bass / } \mathbf{S}\end{array}$ & $\begin{array}{l}\text { Etude } \\
\text { Penjarian } \\
\text { Sendiri }\end{array}$ & $\begin{array}{l}\text { Pusingan } \\
1 \\
\text { (/10) }\end{array}$ & $\begin{array}{l}\text { Pusingan } \\
2 \\
\text { (/10) }\end{array}$ & $\begin{array}{l}\text { Pusingan } \\
\mathbf{3} \\
(/ 10)\end{array}$ & $\begin{array}{l}\text { Pusingan } \\
4 \\
(/ 10)\end{array}$ & $\begin{array}{l}\text { Pusingan } \\
5 \\
(/ 10)\end{array}$ & Jumlah \\
\hline S1 & & 1 & 2 & 5 & 6 & 8 & 22 \\
\hline $\mathrm{S} 2$ & & 0 & 3 & 4 & 6 & 8 & 21 \\
\hline S3 & & 0 & 0 & 1 & 4 & 5 & 10 \\
\hline S4 & & 2 & 3 & 6 & 7 & 8 & 26 \\
\hline S5 & & 1 & 2 & 3 & 6 & 8 & 20 \\
\hline S6 & & 0 & 0 & 0 & 3 & 3 & 6 \\
\hline S7 & & 3 & 3 & 6 & 8 & 8 & 28 \\
\hline S8 & & 0 & 2 & 4 & 6 & 9 & 21 \\
\hline Jumlah & & & & & & & 154 \\
\hline
\end{tabular}

Jadual 12: Dapatan Data Penuh Melalui Penjarian IMR

\begin{tabular}{llllllll}
\hline $\begin{array}{l}\text { Pemain } \\
\text { bass /S }\end{array}$ & $\begin{array}{l}\text { Etude } \\
\text { IMR }\end{array}$ & $\begin{array}{l}\text { Pusingan } \\
1\end{array}$ & $\begin{array}{l}\text { Pusingan } \\
(/ 10)\end{array}$ & $\begin{array}{l}\text { Pusingan } \\
(/ 10)\end{array}$ & $\begin{array}{l}\text { Pusingan } \\
(/ 10)\end{array}$ & $\begin{array}{l}\text { Pusingan } \\
(/ 10)\end{array}$ & $\begin{array}{l}\text { Jumlah } \\
(/ 10)\end{array}$ \\
\hline S1 & 4 & 4 & 8 & 9 & 10 & \\
S2 & 2 & 4 & 8 & 9 & 10 & 35 \\
S3 & 0 & 1 & 4 & 7 & 8 & 20 \\
S4 & 4 & 5 & 8 & 10 & 10 & 37 \\
S5 & 2 & 4 & 6 & 8 & 10 & 30 \\
S6 & 0 & 0 & 4 & 4 & 8 & 16 \\
S7 & 4 & 5 & 8 & 10 & 10 & 37 \\
S8 & 0 & 4 & 8 & 8 & 10 & 30 \\
Jumlah & & & & & & & 211 \\
\hline
\end{tabular}


DOI: https://doi.org/10.47405/mjssh.v5i5.421

\section{Jadual Perbandingan Hasil Projek Pilot Melalui 5 Kali Pusingan}

Jadual 13 merupakan perbandingan jumlah kumpulan mata bagi penjarian sendiri dan penjarian IMR bagi frasa peralihan dan perlintasan. Jumlah mata ini terhasil dari kumpulan mata dari lima kali pusingan. Didapati terdapat perbezaan hasil jumlah iaitu penggunaan penjarian IMR menunjukkan hasil jumlah yang sedikit tinggi berbanding penjarian sendiri. Namun begitu, terdapat juga penghasilan kumpulan jumlah yang sama.

Jadual 13: Perbandingan peralihan dan perlintasan

\begin{tabular}{|c|c|c|c|c|}
\hline Pemain bass /S & Frasa notasi & $\begin{array}{l}\text { Ukuran } 5 \\
\text { kali } \\
\text { pusingan } \\
\text { (penjarian } \\
\text { sendiri) }\end{array}$ & $\begin{array}{l}\text { Ukuran } 5 \\
\text { kali } \\
\text { pusingan } \\
\text { (IMR) }\end{array}$ & Respon \\
\hline S1 & $\begin{array}{l}\text { Peralihan dan } \\
\text { perlintasan }\end{array}$ & 9 & 9 & Merasa sama \\
\hline S2 & $\begin{array}{l}\text { Peralihan dan } \\
\text { perlintasan }\end{array}$ & 6 & 8 & $\begin{array}{l}\text { Jari kuat } \\
\text { menggunakan } \\
\text { IMR }\end{array}$ \\
\hline S3 & $\begin{array}{l}\text { Peralihan dan } \\
\text { perlintasan }\end{array}$ & 5 & 5 & Merasa sama \\
\hline S4 & $\begin{array}{l}\text { Peralihan dan } \\
\text { perlintasan }\end{array}$ & 9 & 10 & $\begin{array}{l}\text { Sedikit selesa } \\
\text { menggunakan } \\
\text { IMR }\end{array}$ \\
\hline S5 & $\begin{array}{l}\text { Peralihan dan } \\
\text { perlintasan }\end{array}$ & 7 & 7 & Merasa sama \\
\hline S6 & $\begin{array}{l}\text { Peralihan dan } \\
\text { perlintasan }\end{array}$ & 2 & 4 & $\begin{array}{l}\text { Mampu } \\
\text { menggunakan } \\
\text { IMR }\end{array}$ \\
\hline S7 & $\begin{array}{l}\text { Peralihan dan } \\
\text { perlintasan }\end{array}$ & 10 & 10 & Merasa sama \\
\hline S8 & $\begin{array}{l}\text { Peralihan dan } \\
\text { perlintasan }\end{array}$ & 6 & 8 & $\begin{array}{l}\text { Sedikit selesa } \\
\text { menggunakan } \\
\text { IMR }\end{array}$ \\
\hline
\end{tabular}

Jadual 14 merupakan perbandingan jumlah kumpulan mata bagi penjarian sendiri dan penjarian IMR bagi frasa melentur. Jumlah mata ini terhasil dari kumpulan mata dari lima kali pusingan. Didapati terdapat perbezaan hasil jumlah iaitu penggunaan penjarian IMR menunjukkan hasil jumlah yang sedikit tinggi berbanding penjarian sendiri. Namun begitu, terdapat juga penghasilan kumpulan jumlah yang sama.

Jadual 14: Perbandingan melentur (B)

\begin{tabular}{lllll}
\hline $\begin{array}{l}\text { Pemain bass } \\
\text { /S }\end{array}$ & Frasa notasi & $\begin{array}{l}\text { Ukuran 5 kali } \\
\text { pusingan } \\
\text { (penjarian } \\
\text { sendiri) }\end{array}$ & $\begin{array}{l}\text { Ukuran 5 kali } \\
\text { pusingan } \\
\text { (IMR) }\end{array}$ & Respon \\
\hline S1 & Melentur (B) & 3 & 10 & $\begin{array}{l}\text { Selesa menggunakan } \\
\text { IMR }\end{array}$ \\
S2 & Melentur (B) & 6 & 10 & $\begin{array}{l}\text { Jari kuat } \\
\text { menggunakan IMR } \\
\text { Mampu } \\
\text { menggunakan IMR }\end{array}$ \\
S3 & Melentur (B) & 1 & 5 & \\
\hline
\end{tabular}


DOI: https://doi.org/10.47405/mjssh.v5i5.421

\begin{tabular}{|c|c|c|c|c|}
\hline S4 & Melentur (B) & 3 & 10 & $\begin{array}{l}\text { Selesa menggunakan } \\
\text { IMR }\end{array}$ \\
\hline S5 & Melentur (B) & 2 & 8 & $\begin{array}{l}\text { Jari bergerak pantas } \\
\text { mengguna IMR }\end{array}$ \\
\hline S6 & Melentur (B) & 0 & 4 & $\begin{array}{l}\text { Selesa menggunakan } \\
\text { IMR }\end{array}$ \\
\hline S7 & Melentur (B) & 3 & 10 & $\begin{array}{l}\text { Selesa menggunakan } \\
\text { IMR }\end{array}$ \\
\hline S8 & Melentur (B) & 4 & 8 & $\begin{array}{l}\text { Sedikit selesa } \\
\text { menggunakan IMR }\end{array}$ \\
\hline
\end{tabular}

Jadual 15 merupakan perbandingan jumlah kumpulan mata bagi penjarian sendiri dan penjarian IMR bagi frasa pull off dan hammer on. Jumlah mata ini terhasil dari kumpulan mata dari lima kali pusingan. Didapati terdapat perbezaan hasil jumlah iaitu penggunaan penjarian IMR menunjukkan hasil jumlah yang sedikit tinggi berbanding penjarian sendiri. Namun begitu, terdapat juga penghasilan kumpulan jumlah yang sama.

Jadual 15: Perbandingan Pull off (PO), hammer on (HO)

\begin{tabular}{lllll}
\hline $\begin{array}{l}\text { Pemain } \\
\text { bass /S }\end{array}$ & Frasa notasi & $\begin{array}{l}\text { Ukuran 5 } \\
\text { kali } \\
\text { pusingan } \\
\text { (penjarian } \\
\text { sendiri) }\end{array}$ & $\begin{array}{l}\text { Ukuran 5 } \\
\text { kali } \\
\text { pusingan } \\
\text { (IMR) }\end{array}$ & Respon \\
\hline S1 & $\begin{array}{l}\text { Pull off (PO), hammer } \\
\text { on (HO) }\end{array}$ & 4 & 8 & Selesa menggunakan IMR \\
S2 & $\begin{array}{l}\text { Pull off (PO), hammer } \\
\text { on (HO) }\end{array}$ & 5 & 8 & Jari kuat menggunakan \\
& & & IMR
\end{tabular}




\begin{tabular}{|c|c|c|c|c|}
\hline & on $(\mathrm{HO})$ & & & \\
\hline S7 & $\begin{array}{l}\text { Pull off (PO), hammer } \\
\text { on }(\mathrm{HO})\end{array}$ & 7 & 9 & Selesa menggunakan IMR \\
\hline S8 & $\begin{array}{l}\text { Pull off (PO), hammer } \\
\text { on (HO) }\end{array}$ & 4 & 7 & Selesa menggunakan IMR \\
\hline
\end{tabular}

Jadual 16 merupakan perbandingan jumlah kumpulan mata bagi penjarian sendiri dan penjarian IMR bagi frasa Trill. Jumlah mata ini terhasil dari kumpulan mata dari lima kali pusingan. Didapati terdapat perbezaan hasil jumlah iaitu penggunaan penjarian IMR menunjukkan hasil jumlah yang sedikit tinggi berbanding penjarian sendiri. Namun begitu, terdapat juga penghasilan kumpulan jumlah yang sama.

Jadual 16: Perbandingan Trill (tr)

\begin{tabular}{|c|c|c|c|c|}
\hline $\begin{array}{l}\text { Pemain } \\
\text { bass /S }\end{array}$ & Frasa notasi & $\begin{array}{l}\text { Ukuran } 5 \\
\text { kali } \\
\text { pusingan } \\
\text { (penjarian } \\
\text { sendiri) } \\
\end{array}$ & $\begin{array}{l}\text { Ukuran } 5 \text { kali } \\
\text { pusingan } \\
\text { (IMR) }\end{array}$ & Respon \\
\hline $\mathrm{S} 1$ & Trill (tr) & 6 & 8 & $\begin{array}{l}\text { Selesa menggunakan } \\
\text { IMR }\end{array}$ \\
\hline S2 & Trill (tr) & 4 & 7 & $\begin{array}{l}\text { Jari kuat } \\
\text { menggunakan IMR }\end{array}$ \\
\hline S3 & Trill (tr) & 2 & 4 & Merasa sama \\
\hline S4 & Trill (tr) & 8 & 8 & Merasa sama \\
\hline S5 & Trill (tr) & 8 & 7 & Merasa sama \\
\hline S6 & Trill (tr) & 2 & 4 & $\begin{array}{l}\text { Mampu } \\
\text { menggunakan IMR }\end{array}$ \\
\hline S7 & Trill (tr) & 8 & 8 & Merasa sama \\
\hline S8 & Trill (tr) & 6 & 7 & Merasa sama \\
\hline
\end{tabular}




\section{Rumusan}

Menjelang pada zaman kini, daya kreativiti bermuzik yang kian meningkat memerlukan kreativiti teknik khusus dalam dunia persembahan solo bes. Teknik penjarian IMR ini adalah sebuah teknik yang boleh dijadikan sesuatu cara atau alternatif dalam membantu penghasilan persembahan solo bes khususnya untuk frasa yang mencabar, sungguhpun ia bersifat subjektif di kalangan pemain bes untuk memilih penjarian dalam melakukan solo bes. Elemen melodi dan ritma yang tercipta secara spontan atau menerus memerlukan disiplin dalam melatih teknik terutamanya jari yang terlibat dalam penghasilan solo bes apatah lagi pada zaman kini bentuk atau idea improvisasi solo yang bersifat unik dan memerlukan kelainan.

Dari hasil kajian yang telah didapati menunjukkan beberapa penghasilan keputusan yang dapat menyatakan teknik penjarian IMR ini boleh digunapakai dalam melakukkan persembahan solo bes khususnya pada frasa yang tertentu. Data projek pilot yang diperolehi telah memberi penampakkan dan penghasilan yang sangat ketara menjurus penelitian dalam mencapai objektif kajian.

Melalui data projek pilot, dapatan hasil adalah dari penglibatan pengumpulan angka. Jika diperhatikan dari hasil jadual penilaian permainan, terdapat beberapa hasil kiraan yang menunjukkan jumlah senderhana, hampir seiring dan mendominasi. Melalui peralihan dan lintasan, sebanyak $45 \%$ dari penjarian sendiri dan sebanyak 55\% dari penjarian IMR. Hasil peratus ini menunjukkan jumlah hampir seiring dan ada sebab tertentu mengapa penjarian IMR memperolehi lebih peratusan. Antara sebab adalah S2, S4 dan S6 menunjukkan kemampuan memainkan frasa tersebut apabila menggunakan penjarian IMR dengan respon merasa sedikit selesa dan jari merasa kuat. Melalui frasa melentur, penjarian sendiri memperoleh $18 \%$ dan penjarian IMR memperolehi $82 \%$. Ini jelas sekali dari jumlah peratusan didominasi oleh penjarian IMR. Jika dirujuk kepada jumlah peratusan dapatan data keseluruhan (Rujuk lampiran C) hasil pengiraan jadual 10 dan jadual 11, penjarian IMR telah mengutip sebanyak $53 \%$, dan manakala penjarian sendiri sebanyak $39 \%$. Ini jelas menunjukkan penjarian IMR lebih menampakkan keberhasilan permainan frasa solo bes tersebut. Selain itu juga, didapati penjarian IMR mendapat respon yang lebih positif kerana kebolehannya memainkan frasa solo bes tersebut. Lebih ramai yang menyatakan rasa selesa apabila menggunakan penjarian IMR berbanding penjarian sendiri. Jari merasa kuat merupakan antara sebab mengapa ia dipilih oleh pemain bass atau responden.

Melalui metodologi projek pilot, kaedah dapatan data ini serba sebanyak membantu dalam membuktikan kadar kemampuan penjarian oleh pelajar itu sendiri dan respon yang didapati selepas frasa dimainkan melalui penjarian sendiri dan penjarian IMR. Ini dapat memberi perbandingan secara praktikal dan seterusnya mampu memberi hasil rumusan.

Persoalan bagi pemasalahan dan objektif kajian juga telah terjawab melalui proses perjalanan tesis ini. Peralihan dan perlintasan jari dalam persembahan solo bes, teknik melentur dan artikulasi hammer on, pull off serta trill menggunakan penjarian IMR telah dibuktikan melalui pilot projek dan dapatan kajian. Kaedah ini telah menampakkan secara praktikalnya keberkesanan teknik penjarian IMR ini dalam menghasilkan data yang menjawab persoalan dan objektif kajian.

\section{Rujukan}

Baker, T.L. (1994). "Doing Social Research (2 $2^{\text {nd }}$ Edn.), New York, Mc Graw - Hill Inc. Simon McKerrell, ICMuS, Newcastle University, Transcription Notes for traditional music.

Teijlingen dan Hundley (2001). "The Important of Pilot Studies". Social Research Update, University of Surrey.

Cochran, WG, \& Cox, GM (1992). "Experimental Designs (2 ${ }^{\text {nd }}$ Edition), New York: John Wiley \& Sons.

Rachel, (2011). "The Double Bass Classroom, NZSO Music for School

Taylor Bob, (2000). "The Arts of Improvisation". Versi 1.0, Taylor: James publications.

Todd, J. (2008). "Todd Johnson Electric Bass Technique Builders”, Suzuki Bass School Volume 1. Alfred Music. 
Malaysian Journal of Social Sciences and Humanities (MJSSH), Volume 5, Issue 5, (page 157 - 174), 2020

DOI: https://doi.org/10.47405/mjssh.v5i5.421

Danelle, Antonia, (2005). "Introduction to Rubrics" An Assessment Tool to Save Grading Time, Convey Effective Feedback, and Promote Student Learning. Stylus Publishing, LLC. 